\title{
In Vivo Toxicity and the Antioxidant Activity of the Hot Water Extract of Glechoma Hederacea
}

\author{
Yun-Chin Chung \\ Providence University \\ Jiunn-Wang Liao \\ National Chung Hsing University \\ Kuo-Yuan Li \\ Providence University \\ Jyun-Kai Jhan \\ Providence University \\ Su-Tze Chou ( $\nabla$ stchou@pu.edu.tw ) \\ Providence University
}

\author{
Research \\ Keywords: Glechoma hederacea, acute toxicitytest, 28-day feeding toxicity tests, subacute toxicity test \\ Posted Date: July 17th, 2020 \\ DOI: https://doi.org/10.21203/rs.3.rs-42365/v1 \\ License: (a) This work is licensed under a Creative Commons Attribution 4.0 International License. Read Full License
}




\section{Abstract \\ Background}

Glechoma hederacea belongs to the Labiatae family and has many biological effects. Our previously in vitro studies, hot water extract of $G$. hederacea (HWG) possessed antioxidant and anti-inflammatory activities. Also, the Ames test indicated that HWG had no mutagenicity. However, the in vivo toxicity and antioxidant capacity have not been clearly demonstrated. Thus, this study was aimed to evaluate the antioxidant properties and the safety level of HWG by using animal models.

\section{Methods}

The genotoxicity were performed by micronucleus assays in mice. Acute oral toxicity and 28-day repeated feeding toxicity tests were performed via the oral gavage method for Sprague-Dawley (SD) rats. Furthermore, the effect of HWG on the oxidation-antioxidation equilibrium of male rats was also evaluated.

\section{Results}

HWG did not induce an increase in micronucleus ratios in vivo, no acute lethal effect at a maximum tested dose of $5.0 \mathrm{~g}$ HWG $/ \mathrm{kg}$ bw was observed in rats. The 28-day oral toxicity study revealed the no observed adverse effect level (NOAEL) of HWG in rats was $1.0 \mathrm{~g} / \mathrm{kg}$ bw. The HWG-treatment significantly elevated the vitamin C level and the SOD activity in heart, and increased the vitamin E concentrations in brain. The HWG-treatment maintained the balance of the glutathione level and the activities of catalase and glutathione peroxidase. Besides, the level of lipid peroxidation and plasma of total antioxidant status (TAS) showed that HWG-treated rats were not significantly changed compared with the control group.

\section{Conclusions}

HWG had no genotoxicity, and did not induce acute or subacute toxicity in SD rat. The level of no observed adverse effect level (NOAEL) of HWG rats was $1.0 \mathrm{~g} / \mathrm{kg}$ bw for subacute toxicity study. HWG possessed antioxidant potential and reduced oxidative stress by improving the antioxidant system in animal.

\section{Background}

Glechoma hederacea, a perennial hairy herb with creeping stem, belongs to the Labiatae family and is known as 'ground ivy', 'creeping Charlie' or 'grillover-the-ground [1]. It can be found commonly in moist areas and caused a problem of overgrowing weed in lawns. Due to their vigorous growth, $G$. hederacea spreads extensively and pushes out native plant. Therefore, the control of $G$. hederacea becomes an important issue in herbaceous borders. According to ancient Chinese prescriptions, G. hederacea was used in treating abscess, arthritis, asthma, cold, cough, diabetes, flu, gastric diseases, headache, hypochondria, inflammation, jaundice and scurvy [1-4]. Ursolic acid and oleanolic acid from $G$. hederacea showed anti-tumor effects on 12-O-tetradecanylphorbol-13-acetate-induced skin tumor [4]. The methanolic extract of $G$. hederacea showed antimicrobial effect against several gram positive and negative bacteria with a minimal inhibition concentration of $5.00-6.25 \cdot 10^{-2} \mathrm{mg} / \mathrm{mL}$ [1], and two unique alkaloids, hederacine A and hederacine B, were isolated from the methanolic extract of $G$. hederacea [3]. The hot water extract of $G$. hederacea could inhibit lipopolysaccharide-induced inflammatory mediator release, including nitric oxide, interleukin (IL)-12p70, and tumor necrosis factor-a. On the other hand, it increased lipopolysaccharide-induced IL-12p40 production [2]. The main components of $G$. hederacea associated with anti-inflammatory activities were believed to be flavonoids and rosmarinic acid [5]. The $n$-hexane, dichloromethane and methanol extracts of $G$. hederacea exhibited DPPH radical-scavenging ability with $\mathrm{IC}_{50}$ values of $1.94 \cdot 10^{-4}, 2.80 \cdot 10^{-3}$ and $1.47 \cdot 10^{-2} \mathrm{mg} / \mathrm{mL}$, respectively [1]. Supporting evidences indicated that $G$. hederacea extracts are rich in polyphenols, which may provide antioxidant, anti-inflammatory, anti-melanogenic, anti-tumor, and hepatoprotective activities [6-9].

The Council of Europe lists $G$. hederacea as a natural source of food flavoring [5]. In China, the decoction of $G$. hederacea is used for ear and toothache. The most common current usage of $G$. hederacea is in the form of tea by infusing ground leaves in boiling water. $G$. hederacea tea is believed to be rich in iodine, vitamin C, and iron and is generally recognized as a good source of vitamins [10]. Our previous in-vitro study showed that hot water extract of $G$. hederacea (HWG) possessed antioxidant and anti-inflammatory characteristics owing to the presence of polyphenolic compounds [11-12]. The antioxidant activities of HWG were significantly higher than those of vitamin $\mathrm{C}$ and trolox in terms of superoxide anion radical-scavenging activity and $\mathrm{Fe}^{2+}$-chelating ability. Results of Ames test indicated that HWG had marked inhibition effects against the mutagenicities of the diagnostic mutagens with the metabolic activator system (S9 mix). In this study, we further used Sprague-Dawley rats as a testing model to confirm the antioxidant potential of HWG.

To apply HWG as an anti-mutagen or antioxidant agent, we have to ascertain its safety level. However, no clinical trials have been performed on $G$. hederacea [5], and the safety of G. hederacea has not been reported yet. In the present study, safety of HWG was assessed with regarding of its 
genotoxicity and acute and subchronic toxicity.

\section{Materials And Methods Chemicals}

Cyclophosphamide (Product NO. C0768) were purchased from Sigma-Aldrich (MO, USA.). All other chemicals were reagent grade or purer.

Preparation of water extract of G. hederacea

G. hederacea was planted in pots and the plants were harvested when the leaves grew up to 4-5 cm in diameter, which took about 2-3 weeks of growth during spring time (temperature around $20-25^{\circ} \mathrm{C}$ ). The $\mathrm{G}$. hederacea extracts were prepared in accordance with our previously reported procedures [11-12]. Briefly, fresh plants were extracted with distilled water at $100^{\circ} \mathrm{C}$ for $3 \mathrm{~h}$ using a heating mantle (NEW LAB MN-30000, Sunray Science Co., Ltd., Taipei, Taiwan). The decoctions were filtered, and then dried by a vacuum freeze-dryer. The extracts were sealed in plastic bottles and stored at $-70^{\circ} \mathrm{C}$ until use.

\section{Mouse Erythrocyte Micronucleus Assay}

Weaned (six week old) and healthy (approval of the serology, parasitology and microbiology examinations) male and female mice (ICR strain, body weight: 25-35 g) obtained from Biolasco Taiwan Co., Ltd. (I-Lan, Taiwan) were housed in stainless steel cages (5 per cage, cage size: D29.5 × W18.8 $\times 13.0 \mathrm{~cm}$ ) bedding with aspen chips (Nepco, U.S.A.) and provided regular diet (Fu-So pellet chow, Taichung, Taiwan) and water ad libitum. The stainless steel cages were kept at $25 \pm 2{ }^{\circ} \mathrm{C}, 65 \pm 5 \%$ relative humidity and a 07:00-19:00 $\mathrm{h}$ lighting period. This study was approved by the animal research ethics committee at Providence University, Taichung, Taiwan (Approval No: 20111215-A03).

The micronucleus assay was conducted according to Krishna and Hayashi [13] and Organization for Economic Cooperation and Development (OECD) [14]. Five mice were allocated randomly to each group. The mice were given HWG at a limited dose of $1.25,2.50 \mathrm{or} 5.00 \mathrm{~g} / \mathrm{kg}$ bw by oral gavage at 09:00-11:00 am daily. The administered volume was $0.2 \mathrm{ml}$. The CP group, as the positive control, was intraperitoneal injected with $0.04 \mathrm{~g} / \mathrm{kg}$ bw of cyclophosphamide. After dosing, the animals were examined for mortality and clinical signs. The animals were anesthetized using $\mathrm{CO}_{2}$, and $100 \mathrm{~L} \mathrm{~L}$ of orbital peripheral blood was withdrawn at 48 and $72 \mathrm{~h}$. Slides were prepared for staining with $0.1 \%$ acridine orange hemi. The reticulocytes (RETs), which stained orange, and the micronuclei $(\mathrm{Mn})$ in the RETs, which stained yellow-green, on each slide were counted under a florescence microscope (Eclipse 50i, Nikon, Japan) with blue excitation $(450 \sim 490 \mathrm{~nm})$ and a barrier filter $(520 \mathrm{~nm})$. In total, 1000 RETs per animal were analyzed for the existence of $\mathrm{Mn}$. The ratio of RETs to normochromatic erythrocytes (NCEs) was determined based on 1000 NCEs. The Mn-to-NCE ratio was recorded while counting 1000 RETs per animal and the Mn-RETs/1000 RETs (\%o) was calculated.

\section{Acute And Subacute Toxicity Tests In Rats}

\section{Animals and diets}

Weaned (five week old) SD male rats (body weight: 140-170 g) and female (body weight: 120-150 g) rats purchased from the Biolasco Taiwan Co., Ltd. (I-Lan, Taiwan) were used. The rats were acclimatized for 1 week prior to starting the experiment. Each rat was caged in a stainless steel cage (cage size: D47.3 × W25.5 × 21.5 cm) individually under controlled environmental conditions $\left(22 \pm 2{ }^{\circ} \mathrm{C}, 65 \pm 5 \%\right.$ relative humidity, 07:00-19:00 h lighting period). The rats were allowed free access to commercial basic diets (Fu-So pellet chow Taichung, Taiwan) and water. The food intake was recorded every day, and the rats were weighed weekly. All the animals received humane care according to the guidelines of the Guidebook for the Care and Use of Laboratory Animals [15]. The study protocol was approved by the animal research ethics committee at Providence University, Taichung, Taiwan (Approval No: 20111215-A03).

\section{Acute Oral Toxicity Study}

A single dose of the test substance $(1.00$ and $5.00 \mathrm{~g} / \mathrm{kg} \mathrm{bw})$ was gavaged to 10 male and 10 female rats. The administered volume was $1.0 \mathrm{ml}$. The water ad libitum was used as the vehicle for the acute and subacute studies. The animals were observed carefully for any signs of morbidity and mortality immediately after dosing, at $4 \mathrm{~h}$ and at $24 \mathrm{~h}$ and intervals, and twice daily for 14 days. The animals were sacrificed under $\mathrm{CO}_{2}$ after 14 days following an overnight fast, and a thorough necropsy was performed on all the animals.

\section{Subacute Oral Toxicity Study}

Ten rats were allocated with body weight-based randomization to four groups, including control (water) and HWG treated groups ( 0.25 , 0.50 and $1.00 \mathrm{~g} / \mathrm{kg} \mathrm{bw}$ ) for each sex. Each group consisted of 10 males and 10 females, and the rats were gavaged daily with HWG (1.0 mL) at 9:00-11:00 am 
for 28 days. The limited dose level of HWG at $1.00 \mathrm{~g} / \mathrm{kg}$ bw/day was selected for the high dose group, and $0.25 \mathrm{~g} / \mathrm{kg}$ bw/day was considered the lowdose group. Clinical signs and mortality were observed twice daily. The food intake of the rat was recorded every day. The rats were weighed weekly. At the end of the 28-day treatment period, the animals fasted overnight and were sacrificed under $\mathrm{CO}_{2}$. A 1-mL whole blood sample was taken from the abdominal aorta in an EDTA- containing tube (K3 EDTA syringes, product NO. 367835, Vacutainer, NJ, USA.) for the complete blood count (CBC) assay, and serum was obtained from $5 \mathrm{~mL}$ of whole blood in Vacutainer tubes (Product NO. 367955, Insepack, Japan) by centrifugation (Kubota 2010, Japan) at $775 \mathrm{xg}$ for $10 \mathrm{~min}$ at $4^{\circ} \mathrm{C}$.

\section{Hematology Examination}

Complete blood count (CBC) was examined by an automated hematology analyzer (Sysmex K-4500, Toa Medical Electronics Co., Ltd., Kobe, Japan) at a commercial analytical service center (Lian-Ming Co., Taichung, Taiwan). The white blood cell count (WBC), red blood cell count (RBC), hemoglobin (HGB), hematocrit (HCT), mean corpuscular volume (MCV), mean corpuscular hemoglobin (MCH), mean corpuscular hemoglobin concentration $(\mathrm{MCHC})$ and platelet (PLT) counts were measured.

\section{Biochemical Examinations}

The serum sample was used to determine the alkaline phosphatase (ALP), the total cholesterol, triglycerides, glucose, aspartate aminotransferase (AST), alanine aminotransferase (ALT), albumin, total bilirubin, glucose, blood urine nitrogen (BUN), and creatinine by enzymatic methods using an automatic analyzer (Synchron CX-7 systems, Beckman Coulter, Fullerton, Calif., U.S.A.) at a commercial analytical service center (Lian-Ming Co., Taichung, Taiwan).

\section{Autopsy And Histology}

All the animals, including those in the erythrocyte micronucleus assay and the acute / subacute toxicity tests, were subjected to necropsy, and the organ weights, histopathological examinations and biochemical analyses were evaluated. The morphologies of all the glands were examined visually, and all the organs were observed macroscopically. Selected vital organs (including the heart, liver, spleen, and kidney) were excised, blotted and weighted. Vital organs included brain, heart, liver and kidneys were examined grossly and weighed. Relative organ weight (\%) is calculated as organ weight (g) / final body weight $(\mathrm{g}) \times 100$. The tissues were fixed in a $10 \%$ buffered formaldehyde solution and embedded in paraffin. The paraffin wax was cut into $2 \mu \mathrm{m}$ sections, stained with hematoxylin and eosin, and examined under light microscopy (Opticphot-2, Nikon, Tokyo, Japan) for the histological examinations.

\section{Antioxidant Activity In Rats Tissue sampling and preparation}

After 28 days of feeding, food was withheld overnight and the rats were sacrificed by decapitation the next morning. The livers, heart, and brains in male rates were subjected for assessment of the antioxidant status. One portion of this tissue was immediately homogenized $(0.3 \mathrm{~g} / \mathrm{mL})$ in ice-cold $0.05 \mathrm{~mole} / \mathrm{L}$ phosphate buffer $(\mathrm{pH} 7.4)$ using a Potter-Elvehjem-type homogenizer with a Teflon pestle and then centrifuged at $12,000 \times \mathrm{g}, 4^{\circ} \mathrm{C}$ for 10 min (Himac CF 16 RX, Hettich, Tokyo, Japan). The supernatant was used for determining the activities of antioxidant-related enzymes including CAT, SOD, and GPx, and lipid peroxidation and the concentrations of ascorbic acid (vitamin C), vitamin E, GSH and MDA were assessed as well.

\section{Lipid Peroxidation Measurement}

The extent of tissue lipid peroxidation was determined by malonaldehyde- thiobarbituric acid (MDA-TBA) adduct according to the method described by Tatum et al [16]. MDA-TBA adduct standard was prepared by reacting 1,1,3,3-tetraethoxy propane (TEP) with TBA under acid condition.

\section{Antioxidants And Plasma Of Total Antioxidant Status (tas) Measurement}

The serum sample was used to determine TAS status. The TAS was measured by the colorimetric technique as described by Miller et al [17], using a commercialized kit (Randox Laboratoratories Ltd, UK), in which 2,2'-azinobis-(3-ethyl benzothiazoline-6-sulphonic acid (ABTS) is incubated with metmyoglobin and $\mathrm{H}_{2} \mathrm{O}_{2}$ to produce radical cations. The absorbance of $734 \mathrm{~nm}$ was monitored, and this absorbance was proportional inversely to the antioxidant capacity of the tested substance. The data of TAS was expressed as a trolox equivalent.

The levels of vitamin $\mathrm{C}$ and $\mathrm{E}$ in the tissues were measured by using HPLC with electrochemical detection according to the method of Mitton and Trevithick [18]. Reduced glutathione (GSH) in tissue homogenates were analyzed by HPLC with fluorimetric detection as previously described [19]. 
CAT activity was determined spectrophotometricaly using $\mathrm{H}_{2} \mathrm{O}_{2}$ as the substrate [20]. The rate of $\mathrm{H}_{2} \mathrm{O}_{2}$ dismutated to $\mathrm{H}_{2} \mathrm{O}$ and $\mathrm{O}_{2}$ was proportional to the CAT activity. The decrease in $\mathrm{H}_{2} \mathrm{O}_{2}$ amount was monitored at $240 \mathrm{~nm}$ at every $15 \mathrm{~s}$ interval over 1 min period. One unit of CAT activity was defined as $1 \mathrm{mM} \mathrm{H}_{2} \mathrm{O}_{2}$ remaining / min. Specific activity of the enzyme was expressed as unit / $\mathrm{mg}$ protein.

The activity of SOD in tissue homogenate was assayed by the inhibition of autoxidation of pyrogallol as described by Marklund and Marklund [21]. Tissue supernatant was mixed with equal volume of $1 \%$ triton $\mathrm{x}-100$ on ice for $30 \mathrm{~min}$. After centrifuged at $9300 \times \mathrm{g}$ for $5 \mathrm{~min}\left(4^{\circ} \mathrm{C}\right)$, the supernatant was collected for SOD activity analysis. A final $3.017 \mathrm{~mL}$ volume of the reaction systems contained $10 \mu \mathrm{L}$ sample, $3 \mathrm{~mL}$ of $50 \mathrm{mM}$ sodium phosphate buffer containing $0.1 \mathrm{mM}$ ethylenediamine tetraacetic acid (EDTA, pH 8.0) and $0.7 \mu \mathrm{L} 50 \mathrm{mM}$ pyrogallol, and the absorbance was recorded every 15 $\mathrm{sec}$ for $5 \mathrm{~min}$ at $420 \mathrm{~nm}$. One unit of SOD activity was defined as the amount of enzyme required for producing half maximal inhibition of autoxidation.

GPx activity in the supernatant was measured as described by Paglia and Valentine [22]. Briefly, the assay mixture consisted of $0.62 \mathrm{~mL}$ of $250 \mathrm{mM}$ phosphate buffer (pH 7.4), $50 \mu \mathrm{L}$ of $40 \mathrm{mM} \mathrm{GSH}, 0.2 \mathrm{~mL}$ of 5 unit/mL GSH reductase, $10 \mu \mathrm{L}$ of $20 \mathrm{mM} \mathrm{NADPH}$ and $0.1 \mathrm{~mL}$ of tissue supernatant. The reaction was started by the addition of $20 \mu \mathrm{L}$ of $15 \mathrm{mM}$ cumene hydroperoxide. Conversion of NADPH to NADP ${ }^{+}$was monitored continuously at $340 \mathrm{~nm}$ for $4 \mathrm{~min}$. One unit of GPx activity was defined as the amount of enzyme that catalyzed the oxidation of $1 \mu \mathrm{mole}$ of NADPH / minute. Specific activity of the enzymes was as unit / mg of protein. Protein concentration of supernatant protein was determined by bicinchoninic acid (BCA) method using bovine serum albumin as the standard [23].

\section{Statistical analysis}

Data were expressed as the mean \pm standard deviation in each group. Mean values were compared by student's $t$ test or analysis of variance (ANOVA) [24] using the SPSS 10.0 software (Spss Inc., Chicago, IL, USA). A significance level of 5\% was adopted for all comparisons.

\section{Results}

\section{Effect of HWG on Mouse Micronuclei}

In the micronucleus tests, the mice were gavage with HWG up to $5.00 \mathrm{~g} / \mathrm{kg}$ bw. No clinical or body weight changes were noted in the tested mice (data not shown). Cyclophosphamide (CP), a diagnostic mutagen, caused an increase in the quantity of micronucleated reticulocytes (Mn-RET) and a decrease in the number of reticulocytes (RET) indicated that CP not only caused the damage of nucleus, but also inhibited or retarded, at least, the maturation of erythrocyte (Table 1). The frequency of micronucleus ratios (Mn-RET/1000 RET) in the male mice for the negative control (without any treatment) was $0.80 \pm 0.83$ and $0.60 \pm 0.55$ at $48 \mathrm{~h}$ and $72 \mathrm{~h}$ for male rats, respectively, and $0.50 \pm 1.00$ and $0.80 \pm 0.84$ at $48 \mathrm{~h}$ and $72 \mathrm{~h}$ for female rats, respectively. The Mn-RET/1000 RET of All the HWG-treated animals were within the normal range of $0.60 \sim 1.00 \%$. Compared with negative control (normal mice), the RET/1000 RBC of the treated mice showed no difference indicating that HWG did not affect maturation of erythrocytes. 
Table 1

Changes of micronuclear counts of reticulocytes in peripheral blood of ICR mice treated with HWG.

\begin{tabular}{|c|c|c|c|c|c|}
\hline \multirow[t]{3}{*}{ Group } & \multirow[t]{3}{*}{ dose $(\mathrm{g} / \mathrm{kg})$} & \multicolumn{2}{|l|}{$48 \mathrm{hr}$} & \multicolumn{2}{|l|}{$72 \mathrm{hr}$} \\
\hline & & Mn-RET / & RET / & Mn-RET / & RET / \\
\hline & & 1000 RET & 1000 RBC & 1000 RET & $1000 \mathrm{RBC}$ \\
\hline \multicolumn{6}{|l|}{ Male } \\
\hline $\mathrm{NC}$ & & $0.80 \pm 0.83$ & $32.80 \pm 3.49$ & $0.60 \pm 0.55$ & $31.00 \pm 4.18$ \\
\hline $\mathrm{CP}$ & 0.06 & $31.20 \pm 2.59^{\square}$ & $5.80 \pm 1.09^{\square}$ & $13.60 \pm 1.67^{\square}$ & $10.20 \pm 1.92^{\square}$ \\
\hline HWG & 5.00 & $0.60 \pm 0.89$ & $36.00 \pm 2.55$ & $0.60 \pm 0.55$ & $34.60 \pm 3.58$ \\
\hline HWG & 2.50 & $0.60 \pm 0.89$ & $34.80 \pm 4.66$ & $0.60 \pm 0.55$ & $33.80 \pm 3.56$ \\
\hline HWG & 1.25 & $1.00 \pm 0.70$ & $34.40 \pm 4.04$ & $1.00 \pm 0.71$ & $34.60 \pm 3.97$ \\
\hline \multicolumn{6}{|c|}{ Female } \\
\hline $\mathrm{NC}$ & & $0.50 \pm 1.00$ & $29.00 \pm 2.92$ & $0.80 \pm 0.84$ & $28.80 \pm 3.42$ \\
\hline $\mathrm{CP}$ & 0.06 & $25.50 \pm 4.93^{\square}$ & $7.60 \pm 2.07^{\square}$ & $18.40 \pm 3.13^{\square}$ & $9.80 \pm 1.92^{\square}$ \\
\hline HWG & 5.00 & $0.60 \pm 0.89$ & $29.00 \pm 2.92$ & $0.80 \pm 0.84$ & $29.00 \pm 3.00$ \\
\hline HWG & 2.50 & $0.80 \pm 0.84$ & $30.60 \pm 5.32$ & $0.80 \pm 0.45$ & $29.00 \pm 3.39$ \\
\hline HWG & 1.25 & $0.80 \pm 1.10$ & $30.60 \pm 3.71$ & $0.80 \pm 0.84$ & $29.60 \pm 1.82$ \\
\hline \multicolumn{6}{|c|}{$\begin{array}{l}\text { Mn-RET: micronucleated reticulocyte; RET: reticulocyte; RBC: erythrocyte; NC: negative control; CP: cyclophosphamide control; HWG: hot water } \\
\text { extracts from Glechoma hedracea. }\end{array}$} \\
\hline
\end{tabular}

\section{Effect of HWG on acute and subacute oral toxicity in rats}

Effects Of Heg On The Growth Of Sd Rats

The body weight gain, food efficiency ratio and relative organ weights of the rats in treatment and control groups were not significantly different ( $p>$ 0.05 , data not shown) in this study, no matter of in acute toxicity or subacute oral toxicity studies.

\section{Effects of HWG on acute oral toxicity study in SD rats}

At a single dose of 1.0 or $5.0 \mathrm{~g} / \mathrm{kg}$ bw of HWG, all the treated rats appeared normal during the observation period, and all the animals survived during the experimental period. A thorough autopsy of the treated animals revealed no treatment-related macroscopic changes. The relative organ weight (data not shown) and hematological parameters (data not shown) showed no significant changes in either sex in all the groups. Compared with the control group, low dose HWG-treated male rats showed lower glucose concentration in their serum (Table 2), but still within normal range. The serum biochemical parameters and hematological parameters revealed no treatment-related alterations at the end of the study. None of the histological examinations showed significant findings in the control or HWG groups (data not show). There were no significant clinical signs or death of the rats attributed to treatment. The acute oral $\mathrm{LD}_{50}$ of HWG was greater than $5.0 \mathrm{~g} / \mathrm{kg} \mathrm{bw}$ in the rats. 
Table 2

Serum biochemical parameters of rats treated with HWG by oral gavage for 14 days

\begin{tabular}{|c|c|c|c|c|c|c|c|c|c|c|c|}
\hline $\begin{array}{l}\text { Dose } \\
(\mathrm{g} / \mathrm{kg})\end{array}$ & $\begin{array}{l}\text { Albumin } \\
\text { (g/dL) }\end{array}$ & $\begin{array}{l}\text { BUN } \\
(\mathrm{mg} / \mathrm{dL})\end{array}$ & $\begin{array}{l}\text { Creatinine } \\
(\mathrm{mg} / \mathrm{dL})\end{array}$ & $\begin{array}{l}\text { Glucose, } \\
\text { AC } \\
\text { (mg/dL) }\end{array}$ & $\begin{array}{l}\text { T.protein } \\
\text { (g/dL) }\end{array}$ & $\begin{array}{l}\text { AST/SGOT } \\
(\mathrm{U} / \mathrm{L})\end{array}$ & $\begin{array}{l}\text { ALT/SGPT } \\
(\mathrm{U} / \mathrm{L})\end{array}$ & $\begin{array}{l}\text { ALP } \\
(U / L)\end{array}$ & $\begin{array}{l}\mathrm{T}- \\
\text { bilirubin } \\
\text { (mg/dL) }\end{array}$ & $\begin{array}{l}\text { TG } \\
(\mathrm{mg} / \mathrm{dL})\end{array}$ & $\begin{array}{l}\text { Cholesterol } \\
\text { (mg/dL) }\end{array}$ \\
\hline \multicolumn{12}{|l|}{ Male } \\
\hline control & $\begin{array}{l}3.95 \pm \\
0.15\end{array}$ & $\begin{array}{l}17.90 \pm \\
2.38\end{array}$ & $\begin{array}{l}0.32 \pm \\
0.08\end{array}$ & $\begin{array}{l}202.48 \\
\pm 30.43^{a}\end{array}$ & $\begin{array}{l}6.06 \pm \\
0.22\end{array}$ & $\begin{array}{l}92.50 \pm \\
9.34\end{array}$ & $\begin{array}{l}47.20 \pm \\
9.19\end{array}$ & $\begin{array}{l}383.83 \\
\pm 88.79\end{array}$ & $<0.1$ & $\begin{array}{l}73.30 \pm \\
35.83\end{array}$ & $\begin{array}{l}74.90 \pm \\
12.19\end{array}$ \\
\hline 1.00 & $\begin{array}{l}4.05 \pm \\
0.14\end{array}$ & $\begin{array}{l}17.50 \pm \\
4.14\end{array}$ & $\begin{array}{l}0.31 \pm \\
0.07\end{array}$ & $\begin{array}{l}172.32 \\
\pm 25.98^{b}\end{array}$ & $\begin{array}{l}6.18 \pm \\
0.19\end{array}$ & $\begin{array}{l}89.90 \pm \\
12.82\end{array}$ & $\begin{array}{l}46.70 \pm \\
8.84\end{array}$ & $\begin{array}{l}350.30 \\
\pm 94.23\end{array}$ & $<0.1$ & $\begin{array}{l}81.51 \pm \\
47.95\end{array}$ & $\begin{array}{l}73.70 \pm \\
14.16\end{array}$ \\
\hline 5.00 & $\begin{array}{l}4.05 \pm \\
0.13\end{array}$ & $\begin{array}{l}16.40 \pm \\
2.12\end{array}$ & $\begin{array}{l}0.34 \pm \\
0.05\end{array}$ & $\begin{array}{l}191.72 \\
\pm \\
31.79^{a, b}\end{array}$ & $\begin{array}{l}6.11 \pm \\
0.17\end{array}$ & $\begin{array}{l}90.50 \pm \\
9.62\end{array}$ & $\begin{array}{l}43.90 \pm \\
6.67\end{array}$ & $\begin{array}{l}344.10 \\
\pm 71.37\end{array}$ & $<0.1$ & $\begin{array}{l}72.10 \pm \\
35.67\end{array}$ & $\begin{array}{l}72.80 \pm \\
13.77\end{array}$ \\
\hline \multicolumn{12}{|l|}{ Female } \\
\hline control & $\begin{array}{l}4.31 \pm \\
0.23\end{array}$ & $\begin{array}{l}19.80 \pm \\
6.41\end{array}$ & $\begin{array}{l}0.34 \pm \\
0.08\end{array}$ & $\begin{array}{l}125.40 \\
\pm 42.22\end{array}$ & $\begin{array}{l}6.41 \pm \\
0.30\end{array}$ & $\begin{array}{l}93.60 \pm \\
14.79\end{array}$ & $\begin{array}{l}34.50 \pm \\
2.55\end{array}$ & $\begin{array}{l}155.50 \\
\pm 27.62\end{array}$ & $<0.1$ & $\begin{array}{l}55.00 \pm \\
16.83\end{array}$ & $\begin{array}{l}84.50 \pm \\
17.37\end{array}$ \\
\hline 1.00 & $\begin{array}{l}4.36 \pm \\
0.21\end{array}$ & $\begin{array}{l}17.50 \pm \\
1.72\end{array}$ & $\begin{array}{l}0.33 \pm \\
0.05\end{array}$ & $\begin{array}{l}137.00 \\
\pm 34.08\end{array}$ & $\begin{array}{l}6.43 \pm \\
0.37\end{array}$ & $\begin{array}{l}105.00 \pm \\
27.41\end{array}$ & $\begin{array}{l}33.90 \pm \\
4.65\end{array}$ & $\begin{array}{l}177.30 \\
\pm 53.29\end{array}$ & $<0.1$ & $\begin{array}{l}55.00 \pm \\
13.33\end{array}$ & $\begin{array}{l}93.90 \pm \\
18.52\end{array}$ \\
\hline 5.00 & $\begin{array}{l}4.48 \pm \\
0.25\end{array}$ & $\begin{array}{l}18.10 \pm \\
2.23\end{array}$ & $\begin{array}{l}0.37 \pm \\
0.07\end{array}$ & $\begin{array}{l}125.20 \\
\pm 32.46\end{array}$ & $\begin{array}{l}6.61 \pm \\
0.33\end{array}$ & $\begin{array}{l}123.96 \pm \\
51.63\end{array}$ & $\begin{array}{l}34.54 \pm \\
7.18\end{array}$ & $\begin{array}{l}182.60 \\
\pm 36.32\end{array}$ & $<0.1$ & $\begin{array}{l}50.00 \pm \\
10.15\end{array}$ & $\begin{array}{l}93.40 \pm \\
20.06\end{array}$ \\
\hline \multicolumn{12}{|c|}{$\begin{array}{l}\text { ALP: Alkaline phosphatase; T-bilirubin: Total-bilirubin; BUN: Blood urea nitrogen; TG: Triglyceride; T. protein: Total protein; ALT: Alanine } \\
\text { aminotransferase; AST: Aspartate aminotransferase. }\end{array}$} \\
\hline \multicolumn{12}{|c|}{ Values were means \pm S.D. $(n=10)$ in each group. } \\
\hline Letter & 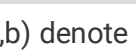 & 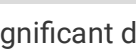 & rence he & 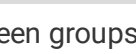 & $0.05)$ & & & & & & \\
\hline
\end{tabular}

\section{Effects of HWG on subacute oral toxicity study in rats}

Compared with the control group, the administration of HWG at a dose of $0.25,0.50$ or $1.00 \mathrm{~g} / \mathrm{kg}$ bw for 28 days did not cause any alterations in the body weight or food intake of the experimental rats (data not shown). The macroscopic appearance of all the organs observed was normal. The relative organ weight (data not shown) and hematological parameters (data not shown) of the treated animals showed no significant changes in both sexes of all the groups.

The serum biochemical parameters revealed no treatment-related alterations at the end of the study (Table 3). Because all the glands and organs were normal in their morphologies examined visually or macroscopically, only the heart, liver, spleen, and kidney were subjected to histopathology. The histological examination of the tissues showed no marked differences between the control and treated groups with respect to any of the organs examined (data not shown). 
Table 3

Serum biochemical parameters of rats treated with HWG by gastric gavage for 28 days

\begin{tabular}{|c|c|c|c|c|c|c|c|c|c|c|c|}
\hline $\begin{array}{l}\text { Dose } \\
(\mathrm{g} / \mathrm{kg})\end{array}$ & $\begin{array}{l}\text { Albumin } \\
\text { (g/dL) }\end{array}$ & $\begin{array}{l}\text { BUN } \\
(\mathrm{mg} / \mathrm{dL})\end{array}$ & $\begin{array}{l}\text { Creatinine } \\
(\mathrm{mg} / \mathrm{dL})\end{array}$ & $\begin{array}{l}\text { Glucose, } \\
\text { AC } \\
\text { (mg/dL) }\end{array}$ & $\begin{array}{l}\text { T.protein } \\
\text { (g/dL) }\end{array}$ & $\begin{array}{l}\text { AST/SGOT } \\
(\mathrm{U} / \mathrm{L})\end{array}$ & $\begin{array}{l}\text { ALT/SGPT } \\
(\mathrm{U} / \mathrm{L})\end{array}$ & $\begin{array}{l}\text { ALP } \\
(U / L)\end{array}$ & $\begin{array}{l}\mathrm{T}- \\
\text { bilirubin } \\
\text { (mg/dL) }\end{array}$ & $\begin{array}{l}\mathrm{TG} \\
(\mathrm{mg} / \mathrm{dL})\end{array}$ & $\begin{array}{l}\text { Cholesterol } \\
(\mathrm{mg} / \mathrm{dL})\end{array}$ \\
\hline \multicolumn{12}{|l|}{ Male } \\
\hline control & $\begin{array}{l}4.29 \pm \\
0.15\end{array}$ & $\begin{array}{l}14.10 \pm \\
1.37\end{array}$ & $\begin{array}{l}0.38 \pm \\
0.06\end{array}$ & $\begin{array}{l}204.90 \\
\pm 33.36\end{array}$ & $\begin{array}{l}6.45 \pm \\
0.66\end{array}$ & $\begin{array}{l}87.40 \pm \\
5.19\end{array}$ & $\begin{array}{l}38.60 \pm \\
8.63\end{array}$ & $\begin{array}{l}194.20 \\
\pm 46.74\end{array}$ & $<0.1$ & $\begin{array}{l}88.80 \pm \\
35.03\end{array}$ & $\begin{array}{l}70.50 \pm \\
23.18\end{array}$ \\
\hline 0.25 & $\begin{array}{l}4.20 \pm \\
0.18\end{array}$ & $\begin{array}{l}13.70 \pm \\
1.57\end{array}$ & $\begin{array}{l}0.39 \pm \\
0.07\end{array}$ & $\begin{array}{l}234.90 \\
\pm 48.49\end{array}$ & $\begin{array}{l}6.70 \pm \\
0.88\end{array}$ & $\begin{array}{l}82.60 \pm \\
11.21\end{array}$ & $\begin{array}{l}39.10 \pm \\
5.53\end{array}$ & $\begin{array}{l}192.10 \\
\pm 45.18\end{array}$ & $<0.1$ & $\begin{array}{l}95.00 \pm \\
34.13\end{array}$ & $\begin{array}{l}81.80 \pm \\
20.68\end{array}$ \\
\hline 0.50 & $\begin{array}{l}4.26 \pm \\
0.21\end{array}$ & $\begin{array}{l}14.40 \pm \\
2.91\end{array}$ & $\begin{array}{l}0.36 \pm \\
0.07\end{array}$ & $\begin{array}{l}223.90 \\
\pm 55.51\end{array}$ & $\begin{array}{l}6.51 \pm \\
0.66\end{array}$ & $\begin{array}{l}80.60 \pm \\
9.01\end{array}$ & $\begin{array}{l}35.20 \pm \\
9.08\end{array}$ & $\begin{array}{l}180.20 \\
\pm 37.17\end{array}$ & $<0.1$ & $\begin{array}{l}95.40 \pm \\
53.69\end{array}$ & $\begin{array}{l}76.50 \pm \\
20.62\end{array}$ \\
\hline 1.00 & $\begin{array}{l}4.23 \pm \\
0.12\end{array}$ & $\begin{array}{l}14.30 \pm \\
1.89\end{array}$ & $\begin{array}{l}0.35 \pm \\
0.05\end{array}$ & $\begin{array}{l}218.90 \\
\pm 54.20\end{array}$ & $\begin{array}{l}6.30 \pm \\
0.56\end{array}$ & $\begin{array}{l}83.50 \pm \\
13.64\end{array}$ & $\begin{array}{l}37.60 \pm \\
7.23\end{array}$ & $\begin{array}{l}188.50 \\
\pm 53.70\end{array}$ & $<0.1$ & $\begin{array}{l}91.90 \pm \\
41.78\end{array}$ & $\begin{array}{l}80.50 \pm \\
19.44\end{array}$ \\
\hline \multicolumn{12}{|l|}{ Female } \\
\hline control & $\begin{array}{l}4.70 \pm \\
0.27\end{array}$ & $\begin{array}{l}17.80 \pm \\
5.81\end{array}$ & $\begin{array}{l}0.39 \pm \\
0.09\end{array}$ & $\begin{array}{l}171.80 \\
\pm 19.07\end{array}$ & $\begin{array}{l}7.25 \pm \\
0.46\end{array}$ & $\begin{array}{l}85.00 \pm \\
12.00\end{array}$ & $\begin{array}{l}36.50 \pm \\
8.30\end{array}$ & $\begin{array}{l}124.50 \\
\pm 44.37\end{array}$ & $<0.1$ & $\begin{array}{l}68.10 \pm \\
56.61\end{array}$ & $\begin{array}{l}86.70 \pm \\
15.56\end{array}$ \\
\hline 0.25 & $\begin{array}{l}4.71 \pm \\
0.28\end{array}$ & $\begin{array}{l}18.60 \pm \\
2.99\end{array}$ & $\begin{array}{l}0.42 \pm \\
0.04\end{array}$ & $\begin{array}{l}168.40 \\
\pm 48.01\end{array}$ & $\begin{array}{l}7.16 \pm \\
0.47\end{array}$ & $\begin{array}{l}81.30 \pm \\
4.62\end{array}$ & $\begin{array}{l}35.10 \pm \\
7.67\end{array}$ & $\begin{array}{l}112.20 \\
\pm 35.79\end{array}$ & $<0.1$ & $\begin{array}{l}51.00 \pm \\
17.04\end{array}$ & $\begin{array}{l}84.80 \pm \\
18.11\end{array}$ \\
\hline 0.50 & $\begin{array}{l}4.70 \pm \\
0.22\end{array}$ & $\begin{array}{l}16.30 \pm \\
2.79\end{array}$ & $\begin{array}{l}0.37 \pm \\
0.13\end{array}$ & $\begin{array}{l}192.20 \\
\pm 36.45\end{array}$ & $\begin{array}{l}7.21 \pm \\
0.40\end{array}$ & $\begin{array}{l}79.90 \pm \\
9.50\end{array}$ & $\begin{array}{l}35.40 \pm \\
3.78\end{array}$ & $\begin{array}{l}116.50 \\
\pm 26.71\end{array}$ & $<0.1$ & $\begin{array}{l}53.60 \pm \\
13.57\end{array}$ & $\begin{array}{l}94.50 \pm \\
18.83\end{array}$ \\
\hline 1.00 & $\begin{array}{l}4.56 \pm \\
0.34\end{array}$ & $\begin{array}{l}16.40 \pm \\
2.07\end{array}$ & $\begin{array}{l}0.39 \pm \\
0.07\end{array}$ & $\begin{array}{l}183.50 \\
\pm 43.54\end{array}$ & $\begin{array}{l}7.07 \pm \\
0.45\end{array}$ & $\begin{array}{l}84.00 \pm \\
6.93\end{array}$ & $\begin{array}{l}37.40 \pm \\
4.95\end{array}$ & $\begin{array}{l}116.50 \\
\pm 38.30\end{array}$ & $<0.1$ & $\begin{array}{l}51.10 \pm \\
19.94\end{array}$ & $\begin{array}{l}89.30 \pm \\
15.21\end{array}$ \\
\hline \multicolumn{12}{|c|}{$\begin{array}{l}\text { ALP: Alkaline phosphatase; T-bilirubin: Total-bilirubin; BUN: Blood urea nitrogen; TG: Triglyceride; T.protein: Total protein; ALT: Alanine } \\
\text { aminotransferase; AST: Aspartate aminotransferase. }\end{array}$} \\
\hline \multicolumn{12}{|c|}{ Values were means \pm S.D. $(n=10)$ in each group. } \\
\hline
\end{tabular}

Effects of HWG on the antioxidant status in SD rats

\section{Effects Of Hwg On Tbars And Antioxidant Level}

Tissue lipid peroxidation is associated with oxidant stress and MDA is a major secondary product of lipid hydroperoxides. In this study, MDA was measured as MDA- thiobarbituric acid reactive substances (TBARS) adducts using TEP as the standard. Therefore, the concentration of TBARS may reflect the degree of oxidative stress in animals and is usually used for assessing the degree of lipid peroxidation [25]. The levels of TBARS in the brain, heart and liver are presented in Table 4. Compared to the control group, HWG treatment, in all tested concentrations, did not affect significantly the TBARS level of brain, heart or liver in male SD rats $(p>0.05)$. Again, there was no significant difference $(p>0.05)$ in plasma TAS between the control and HWG-treated groups (Table 5). 
Table 4

Antioxidants and lipid peroxidation (MDA) levels in tissues of male rats treated with HWG by oral gavage for 28days

\begin{tabular}{|c|c|c|c|c|}
\hline $\begin{array}{l}\text { Dose } \\
(\mathrm{g} / \mathrm{kg})\end{array}$ & $\begin{array}{l}\text { Vit E } \\
\text { (nmole/mg protein) }\end{array}$ & $\begin{array}{l}\text { Vit C } \\
\text { (nmole/mg protein) }\end{array}$ & $\begin{array}{l}\text { GSH } \\
\text { (nmole/mg protein) }\end{array}$ & $\begin{array}{l}\text { MDA } \\
\text { (nmole/mg protein) }\end{array}$ \\
\hline \multicolumn{5}{|l|}{ brain } \\
\hline control & $1.06 \pm 0.16^{b}$ & $38.54 \pm 5.73$ & $14.58 \pm 2.72$ & $6.72 \pm 1.98$ \\
\hline 0.25 & $1.11 \pm 0.16^{a, b}$ & $39.20 \pm 5.42$ & $14.32 \pm 2.80$ & $8.10 \pm 0.91$ \\
\hline 0.50 & $1.17 \pm 0.13^{a, b}$ & $40.34 \pm 6.22$ & $14.69 \pm 3.16$ & $6.78 \pm 1.44$ \\
\hline 1.00 & $1.23 \pm 0.16^{a}$ & $40.56 \pm 4.60$ & $15.91 \pm 3.27$ & $7.39 \pm 1.62$ \\
\hline \multicolumn{5}{|l|}{ heart } \\
\hline control & $2.25 \pm 0.28$ & $4.29 \pm 0.50^{b}$ & $24.11 \pm 2.74$ & $5.05 \pm 1.00$ \\
\hline 0.25 & $2.02 \pm 0.39$ & $4.33 \pm 0.46^{b}$ & $24.20 \pm 3.44$ & $4.67 \pm 0.74$ \\
\hline 0.50 & $2.26 \pm 0.39$ & $4.74 \pm 0.76^{a, b}$ & $25.48 \pm 2.45$ & $4.58 \pm 1.04$ \\
\hline 1.00 & $2.17 \pm 0.45$ & $4.98 \pm 0.60^{a}$ & $23.94 \pm 2.25$ & $4.66 \pm 0.80$ \\
\hline \multicolumn{5}{|l|}{ liver } \\
\hline control & $0.39 \pm 0.05$ & $9.61 \pm 1.17$ & $28.97 \pm 2.54$ & $2.94 \pm 0.56$ \\
\hline 0.25 & $0.40 \pm 0.07$ & $9.37 \pm 1.02$ & $29.38 \pm 3.23$ & $2.65 \pm 0.84$ \\
\hline 0.50 & $0.40 \pm 0.07$ & $10.01 \pm 1.31$ & $26.68 \pm 3.45$ & $2.71 \pm 0.71$ \\
\hline 1.00 & $0.40 \pm 0.05$ & $10.34 \pm 1.55$ & $27.10 \pm 4.66$ & $2.43 \pm 0.59$ \\
\hline \multicolumn{5}{|c|}{ Values were means \pm S.D. $(n=10)$ in each group. } \\
\hline Letters & denote signif & erence between $\mathrm{g}$ & $s(p<0.05)$. & \\
\hline
\end{tabular}

Table 5

Total antioxidant status of plasma in male rats treated with HWG by oral gavage for 28 days

\begin{tabular}{|ll|}
\hline Dose $(\mathbf{g} / \mathbf{~ k g})$ & Total antioxidant status $(\mathrm{mM}$, as a trolox $)$ \\
\hline control & $4.81 \pm 0.82$ \\
\hline 0.25 & $4.84 \pm 0.71$ \\
\hline 0.50 & $4.99 \pm 0.84$ \\
\hline 1.00 & $5.12 \pm 0.87$ \\
\hline Values were means \pm S.D. $(\mathrm{n}=10)$ in each group. \\
\hline There was no significant different among control and treatment groups $(p>0.05)$. \\
\hline
\end{tabular}

Oral administration of high dose $(1.00 \mathrm{~g} \mathrm{HWG} \mathrm{/} \mathrm{kg} \mathrm{bw)} \mathrm{of} \mathrm{HWG} \mathrm{might} \mathrm{increase} \mathrm{the} \mathrm{vitamin} \mathrm{E} \mathrm{and} \mathrm{C} \mathrm{levels} \mathrm{significantly}(p<0.05)$ in brain and heart, respectively. The levels of GSH in either brain, heart or liver tissues, no matter $0.25 \mathrm{~g} \mathrm{HWG} \mathrm{/} \mathrm{kg} \mathrm{bw,} 0.50 \mathrm{~g} \mathrm{HWG} \mathrm{/} \mathrm{kg} \mathrm{bw} \mathrm{or} 1.00 \mathrm{~g} \mathrm{HWG} \mathrm{/} \mathrm{kg} \mathrm{bw,} \mathrm{were}$ not affected significantly by HWG treatments $(p>0.05)$.

\section{Effects Of Hwg On Activities Of Antioxidant Enzymes}

The effects of HWG on activities of catalase (CAT), glutathione peroxidase (GPx), and superoxide dismutase (SOD) in brain, heart and liver of SD rat are shown in Table 6. Compared with the control, oral administration of HWG could significantly $(p<0.05)$ increased the SOD activity of heart tissues, however, SOD activities of the brains or livers were not affected by HWG $(p>0.05)$. For the catalase or GPx activity, there was no difference was observed between the HWG group and the control $(p>0.05)$. 
Table 6

Antioxidant enzyme activities in tissues of male rats treated with HWG by oral gavage for 28 days

\begin{tabular}{|llll|}
\hline $\begin{array}{l}\text { Dose } \\
\text { (g/kg) }\end{array}$ & $\begin{array}{l}\text { GPx } \\
\text { (unit/mg protein) }\end{array}$ & $\begin{array}{l}\text { CAT } \\
\text { (unit/mg protein) }\end{array}$ & $\begin{array}{l}\text { SOD } \\
\text { (unit/mg protein) }\end{array}$ \\
\hline brain & & & \\
\hline control & $433.41 \pm 72.31$ & $3.62 \pm 0.55$ & $2.59 \pm 0.29$ \\
\hline 0.25 & $443.35 \pm 47.42$ & $3.57 \pm 0.42$ & $2.56 \pm 0.35$ \\
\hline 0.50 & $448.29 \pm 45.45$ & $3.46 \pm 0.54$ & $2.52 \pm 0.35$ \\
\hline 1.00 & $453.47 \pm 57.21$ & $3.55 \pm 0.49$ & $2.51 \pm 0.30$ \\
\hline heart & & & \\
\hline control & $969.57 \pm 105.74$ & $15.76 \pm 2.50$ & $2.74 \pm 0.41^{\mathrm{b}}$ \\
\hline 0.25 & $1064.23 \pm 96.36$ & $17.28 \pm 2.47$ & $3.20 \pm 0.55^{\mathrm{a}}$ \\
\hline 0.50 & $984.76 \pm 144.18$ & $15.78 \pm 2.06$ & $3.20 \pm 0.33^{\mathrm{a}}$ \\
\hline 1.00 & $1003.15 \pm 110.43$ & $16.04 \pm 1.79$ & $3.24 \pm 0.46^{\mathrm{a}}$ \\
\hline liver & & & $4.38 \pm 0.26$ \\
\hline control & $1031.70 \pm 95.49$ & $23.02 \pm 2.30$ & $4.22 \pm 0.22$ \\
\hline 0.25 & $990.05 \pm 74.07$ & $22.57 \pm 2.90$ & $4.30 \pm 0.15$ \\
\hline 0.05 & $978.62 \pm 87.29$ & $22.03 \pm 2.54$ & 4.27 \\
\hline 1.00 & $1027.50 \pm 61.36$ & $21.35 \pm 1.76$ & $4.26 \pm 0.27$ \\
\hline Values were means \pm S.D. (n $=10)$ in each group. & \\
\hline Letters $(\mathrm{a}, \mathrm{b}$ ) denote significant difference between groups $(p<0.05$ ). & \\
\hline & & & \\
\hline
\end{tabular}

\section{Discussion}

In our previous study, the mutagenicity of HWG was assessed by Ames test [11]. Results of Ames test indicated that HWG had no mutagenicity toward all tester strains including Salmonella typhimurium TA97, TA98, TA100, TA102, and TA1535 with / without the metabolic activator (S9 mix). In the present study, the safety level of HWG was further evaluated with animal models including micronucleus test for mutagenicity property, 14 days-single dose and 28 days-repeated dose studies for measuring acute and subacute toxicity. The micronucleus experimental results showed that HWG not only caused no damage to erythrocyte but also did not influent the maturation of erythrocyte.

Animal feeding experiments are commonly used to evaluate the toxic characteristics of specific substances [26]. In the present study of the toxicity of HWG to SD rats, HWG was administered at a single dose of $5.0 \mathrm{~g} / \mathrm{kg}$ bw for acute toxicity or it was given at $1.0 \mathrm{~g} / \mathrm{kg} \mathrm{bw}$ for 28 days for subacute toxicity. The treatment-related changes showed no significant difference in the SD rats. Histopathology has historically been the most consistent criterion to establish the no observed adverse effect level (NOAEL) [27]. Again, the results of the histopathological examination in the acute and subacute toxicity studies revealed that HWG did not cause significantly toxicological effects in the rats, indicating that there was no adverse effect of HWG in rats [26-28]. In vivo studies indicated that a single dose of $5 \mathrm{~g} / \mathrm{Kg}$ bw in a mouse (equal to $3.5 \mathrm{~g} / \mathrm{kg}$ bw in rat) or a single dose of $5.0 \mathrm{~g} / \mathrm{kg}$ bw in the rat or repeated doses of $1.0 \mathrm{~g} / \mathrm{kg}$ bw (equal to $0.16 \mathrm{~g}$ in human adult) for 28 days in rats did not meet the toxicity criteria in the mouse erythrocyte micronucleus assay or the rat acute and subacute toxicity assays.

In vitro study showed that HWG possessed antioxidant characteristics and the antioxidant activities of HWG were significantly higher than those of vitamin $\mathrm{C}$ and trolox in superoxide anion radical-scavenging activity and $\mathrm{Fe}^{2+}$-chelating ability [11]. Therefore, animal model was applied to substantiate the antioxidant properties of HWG. Many researches showed that phytochemicals could decline the TBARS level of liver in tested animals [29]. In the present study, HWG did not show the protection effect on the tissue lipid peroxidation. Antioxidants such as vitamin $\mathrm{C}$, vitamin $\mathrm{E}$ and GSH will provide greater protection to the organs tissues against oxidant damage. Therefore, we evaluated the effect of the supplement of the HWG on the levels of vitamin C, vitamin E and GSH in the brain, heart and liver tissues. The HWG did not improve considerably the concentration of antioxidant substances, in where, HWG only increased vitamin E and C levels in brain and heart, respectively. It is also worth to mention that HWG is not considered as a vitamin $\mathrm{C}$ or $\mathrm{E}$ enriched plant item (approximate $70-80 \mathrm{mg}$ vitamin $\mathrm{C} / \mathrm{g}$ ). In this case, an explanation was needed to address the issue of how the HWG could increase the ascorbic acid or vitamin E level in the brain or heart tissues. Our previous data [11] showed that the HWG exhibited antioxidant activities in vitro. Moreover, HPLC analysis results showed that rosmarinic acid, chlorogenic acid, caffeic acid, rutin, genistin, and 
ferulic acid were the most abundant phytochemicals in HWG and possess potent antioxidant and anti-inflammatory properties [12]. Also, BelščakCvitanović et al [6] extracted phenolic compounds of $G$. hederacea with boiling water and found that the concentrations of caffeic acid, cholrogenic acid and rosmarinic acid were $249.84 \pm 15.09,1300.22 \pm 58.36$ and $3236.56 \pm 45.78 \mathrm{ug} / \mathrm{g}$ dry weight extract, respectively. It is possible that instead of the supplement of ascorbic acid or vitamin E in the brain or heart, the phenolic compounds of HWG might perform direct free radical scavenging activity and preserve more ascorbic acid or vitamin $E$ in the rat with the treatment of the extract. Oral administration of HWG increased the concentration of vitamin E in brains and vitamin C in hearts and the activity of SOD in hearts; on the other hand, the concentration of GSH and the activities of GPx and CAT were maintained and did not induce lipid peroxidation.

\section{Conclusions}

HWG had no genotoxicity, and did not induce acute or subacute toxicity in SD rat. The level of no observed adverse effect level (NOAEL) of HWG rats was $1 \mathrm{~g} / \mathrm{kg}$ bw for subacute toxicity study. HWG possessed antioxidant potential and reduced oxidative stress by improving the antioxidant system in animal.

\section{Abbreviations}

\section{CAT}

catalase; GPx:glutathione peroxidase; GSH:glutathione; HWG:hot water extract of G. hederacea; MDA-TBA:malonaldehyde- thiobarbituric acid; MNRET:micronucleated reticulocyte; NCE:normochromatic erythrocyte; NOAEL:no observed adverse effect level; TAS:total antioxidant status;

SOD:superoxide dismutase.

\section{Declarations}

\section{Ethics approval and consent to participate}

This study involved animal experiments and was approved by the animal research ethics committee at Providence University, Taichung, Taiwan (Approval No: 20111215-A03).

\section{Consent for publication}

Not applicable.

\section{Availability of data and materials}

The datasets used in this study are available from the corresponding author upon reasonable request.

\section{Competing interests}

The authors declare that they have no competing interests.

\section{Funding}

This research received no external funding. The authors are grateful for financial support from the Ministry of Science and Technology, Taiwan (NSC102-2313-B-126-004-MY3).

\section{Authors' Contributions}

Conceived and designed the experiments: ST Chou; Performed the experiments: KY Li, JW Liao, JKJhan; Analyzed the data: KY Li, JW Liao and YC Chung; Wrote the manuscript: YC Chung; Reviewed the manuscript and coordinated the submission processes: ST Chou.All authors had read and approved the final manuscript for submission.

\section{Acknowledgements}

Not applicable.

\section{Conflicts of Interest}

The authors declare no conflicts of interest.

\section{Author details}

${ }^{1}$ Department of Food and Nutrition, Providence University, Taichung, Taiwan. ycchun@pu.edu.tw; sinmiss@msn.com; g9822905@pu.edu.tw; stchou@pu.edu.tw 
${ }^{2}$ Graduate Institute of Veterinary Pathobiology, National Chung Hsing University; jwliao@dragon.nchu.edu.tw

\section{References}

1. Kumarasamy Y, Cox PJ, Jaspars M, Nahar L, Sarker SD. Biological activity of Glechoma hederacea. Fitoterapia. 2002;73:721-23.

2. An HJ, Jeong HJ, Um JY, Kim HM, Hong SH. Glechoma hederacea inhibits inflammatory mediator release in IFN-r and LPS- stimulated mouse peritoneal macrophages. J Ethnopharmacol. 2006;106:418-24.

3. Kumarasamy Y, Cox PJ, Jaspars M, Nahar L, Sarker SD. Isolation, structure elucidation and biological activity of hederacine A and B, two unique alkaloids from Glechoma hederacea. Tetrahedron. 2003;59:6403-07.

4. Tokuda M, Ohigashi H, Koshimizu K, Ito Y. Inhibitory effects of ursolic and oleanolic acid on skin tumor promotion by12-0-tetradecanylphorbol-13acetate. Cancer Lett. 1986;33:279-85.

5. Barnes J, Anderson LA, Phillipson JD. Herbal Medicines. 3rd ed. 6. London: Pharmaceutical Press; 2007. pp. 342-3.

6. Milovanovic M, Zivkovic D, Vucelic-Radovic B. Antioxidant effects of Glechoma hederacea as a food additive. Nat Prod Commun. 2010;5:61-3.

7. Qiao Z, Koizumi Y, Zhang M, Natsui M, Flores MJ, Gao L, et al. Anti-melanogenesis effect of Glechoma hederacea L. extract on B16 murine melanoma cells. Biosci Biotechnol Biochem. 2012;76:1877-83.

8. Wang YY, Lin SY, Chen WY, Liao SL, Wu CC, Pan PH, et al. Glechoma hederacea extracts attenuate cholestatic liver injury in a bile duct-ligated rat model. J Ethnopharmacol. 2017;204:58-66.

9. Chou ST, Lai CC, Lai CP, Chao WW. Chemical composition, antioxidant, anti-melanogenic and anti-inflammatory activities of Glechoma hederacea (Lamiaceae) essential oil. Ind Crop Prod. 2018;122:675-85.

10. Crellin JK, Philpott J. Herbal Medicine Past and Present. Durham: Duke University Press; 1990. pp. 238-40.

11. Chou ST, Chan YR, Chung YC. Studies on the antimutagenicity and antioxidant activity of hot water extract from Glechoma hederacea. J Food Drug Anal. 2012;20:637-45.

12. Chou ST, Lin TH, Peng HY, Chao WW. Phytochemical profile of hot water extract of Glechoma hederacea and its antioxidant, and antiinflammatory activities. Life Sci. 2019;231:116519-28.

13. Krishna G, Hayashi M. In vivo rodent micronucleus assay: protocol, conduct and data interpretation. Mutat Res. 2000;455:155-66.

14. Organization for Economic Cooperation and Development (OECD). Mammalian erythrocyte micronucleus test, In: OECD Guideline for the Testing of Chemicals. OECD Paris, Test Guideline 1997;474.

15. Yu JYL, Cheng CK, Chen BJ, Cheng MJ, Cheng HH, Cheng WJ et al editor, A Guideline for the Care and Use of Laboratory Animals. Taipei, Taiwan, ROC. Chinese Society for the Laboratory Animals Science, 2004;207.

16. Tatum V, Changchit C, Chow C. Measurement of malondialdehyde by high performance liquid chromatography with fluorescence detection. Lipids. 1990;25:226-9.

17. Miller J, Rice- Evans C, Davies J, Gopinathan V, Milner A. A novel method for measuring antioxidant capacity and its application to monitoring the antioxidant status in premature neonates. Clin Sci. 1993;84:407-12.

18. Mitton KP, Trevithick JR. High-performance liquid chromatography-electrochemical detection of antioxidants in vertebrate lens: glutathione, tocopherol, and ascorbate. Method Enzymol. 1994;233:523-39.

19. Chou ST, Ko LE, Yang CS. Determination of tissue a-tocopherol in senescence-accelerated mice by high-performance liquid chromatography with fluorimetric detection. Anal Chim Acta. 2000;419:81-6.

20. Aebi H. Catalase. In: Bergmeyer HU, editors, Methods of Enzymatic Analysis. Academic Press, New York, $1974 ; 673$ - 77.

21. Marklund S, Marklund G. Involvement of the superoxide anion radical in the autoxidation of pyrogallol and a convenient assay for superoxide dismutase. Eur J Biochem. 1974;47:469-74.

22. Paglia DE, Valentine WN. Studies on the quantitative and qualitative characterization of erythrocyte glutathione peroxidase. J Lab Clin Med. 1967;70:158-69.

23. Smith PK, Krohn RI, Hermanson GT, Mallia AK, Gartner FH, Provenzano MD, et al. Measurement of protein using bicinchoninic acid. Anal Biochem. 1985;150:76-85.

24. Steel RGD, Torrie JH. Principles and Procedures of Statistics. New York: McGraw-Hill; 1980.

25. Yokozawa T, Cho EJ, Hara Y, Kitani K. Antioxidative activity of green tea treated with radical initiator 2,2'-azobis(2-amidinopropane) dihydrochloride. J Agric Food Chem. 2000;48:5068-73.

26. Environmental Protection Agency (EPA), Office of Prevention, Pesticides and Toxic Substances. Acute oral toxicity, In: OPPTS Harmonized Test Guidelines, Series 870.1100. EPA 712-C-98-190. Washington, DC. 1998;10.

27. Dorato MA, Engelhardt JA. The no-observed-adverse-effect-level in drug safety evaluations: use, issues, and definition(s). Regul Toxicol Pharm. 2005;42:265-74.

28. Drganization for Economic Cooperation and Developement (OECD). Repeated dose 28-day oral toxicity study in rodents, In: OECD Guideline for the testing of chemicals. Section 4: Health Effects, 407. Adopted by the Council on 3rd October 2008.

Page $12 / 13$ 
29. Tsuda T, Horio F, Osawa T. Dietary cyaniding 3-o- $\beta$-D-glucoside increase ex vivo oxidation resistance of serum in rats. Lipids. 1998;33:583-88.

30. Dodane V, Vilivalam VD. Pharmaceutical applications of chitosan. Pharmaceut Sci Tech Today. 1998;1:246-53.

31. Environmental Protection Agency (EPA). Repeated dose 25-day oral toxicity study in rodents, In: OPPTS Harmonized Tset Guidelines, Series 870. 3050, EPA712-C-00-366. Washington, DC. 2000;10.

32. Tokoro A, Kobayashi M, Tatewaki N, Suzuki K, Okawa Y, Mikami T, et al. Protective effect of N-acetyl-chitohexaose on Listeria monocytogenes infection in mice. Microbiol Immunol. 1989;33:357-67. 